\title{
IRAN IN DIE INTERNASIONALE MAGSTRYD
}

Iran, once the state which, in the midst of political turmoil and military conflict among its Arab neighbours, enjoyed an era of unprecedented economic prosperity and social stability under the administration of the Shah — was suddenly plunged in 1978 into a cultural crisis whose central theme was the common Islamic faith of otherwise diverse groups with disparate political and ideological aspirations.

The Iranian revolution, however, was never a merely regional affair, although it started against the background of purely local political issues. The Persian state, in point of fact, became the focal point of centrifugal power struggle between the superpowers, which had already spread to the entire geopolitical area of the Persian Gulf.

The role of the Soviet Union, which had cleverly used local factions to influence the country's policy, can be seen as particularly significant in view of the present energy crisis and the West's dependence on Gulf oil. The revolution, moreover, marked the end of American power and influence in the region - a fact borne out by the inconsistent and passive attitude displayed by the Americans throughout the crisis.

Meanwhile, it is apparent that the revolution in Iran has left a power vacuum in the region - the country had previously enjoyed close military ties with the US and has played an important security role for the West in acting as a bulwark against Communist domination of the region. With the Islamic state now wavering between a policy of uncommitted neutrality and closer association with the Arabic world, it is possible that continuing internal unrest will lead to the vacillating Bazargan Government giving way to the demands of Communist pressure groups, which enjoy significant support in the workforce of the manufacturing and oil industries.

\section{Inleiding}

The comparison of force is not only comparison of military and economic power, but also that of manpower and the human mind. The physical atomic bomb is important, but the spiritual atomic bomb is even more important. And the spiritual atomic bomb is our monopoly.

In hierdie artikel word die rol van Iran, as 'n komponent van die huidige internasionale magstryd ontleed. Alvorens die rol werklik bepaal kan word moet daar aandag geskenk word aan die verskeie faktore - ekstern sowel as intern - wat die buitelandse beleidsformuleringsproses beïnvloed.

Eerstens word die invloed van Islam, die Moslem-geloof, bepaal. Daarna word daar krities na Iran se rol in die internasionale politiek vóór
1979 gekyk. Laastens word 'n poging aangewend om 'n projeksie van Iran se rol in die internasionale politieke magstryd, huidig en in die volgende dekade te maak.

Iran word deur Irak en Turkye in die Weste, die Kaspiese See en die Sowjet-Unie in die noorde, die Persiese Golf en die Golf van Oman in die suide, Afganistan en Pakistan in die ooste begrens. Iran vorm tans 'n buffer tussen die USSR en die Persiese Golf — die wêreld se olie-slagaar. 'n Ander belangrike feit is dat Iran en die USSR 'n 2000 km grens deel.

Die politieke toneel in die Midde-Ooste is ' $n$ toneel van gedurige verandering. Om die politieke situasie in die Midde-Ooste te wil ontleed moet al die belangrike politieke en militêre probleme in die wêreld ook in ag geneem word, want dit oefen 'n groot invloed op die Midde-Oosterse politiek uit. 


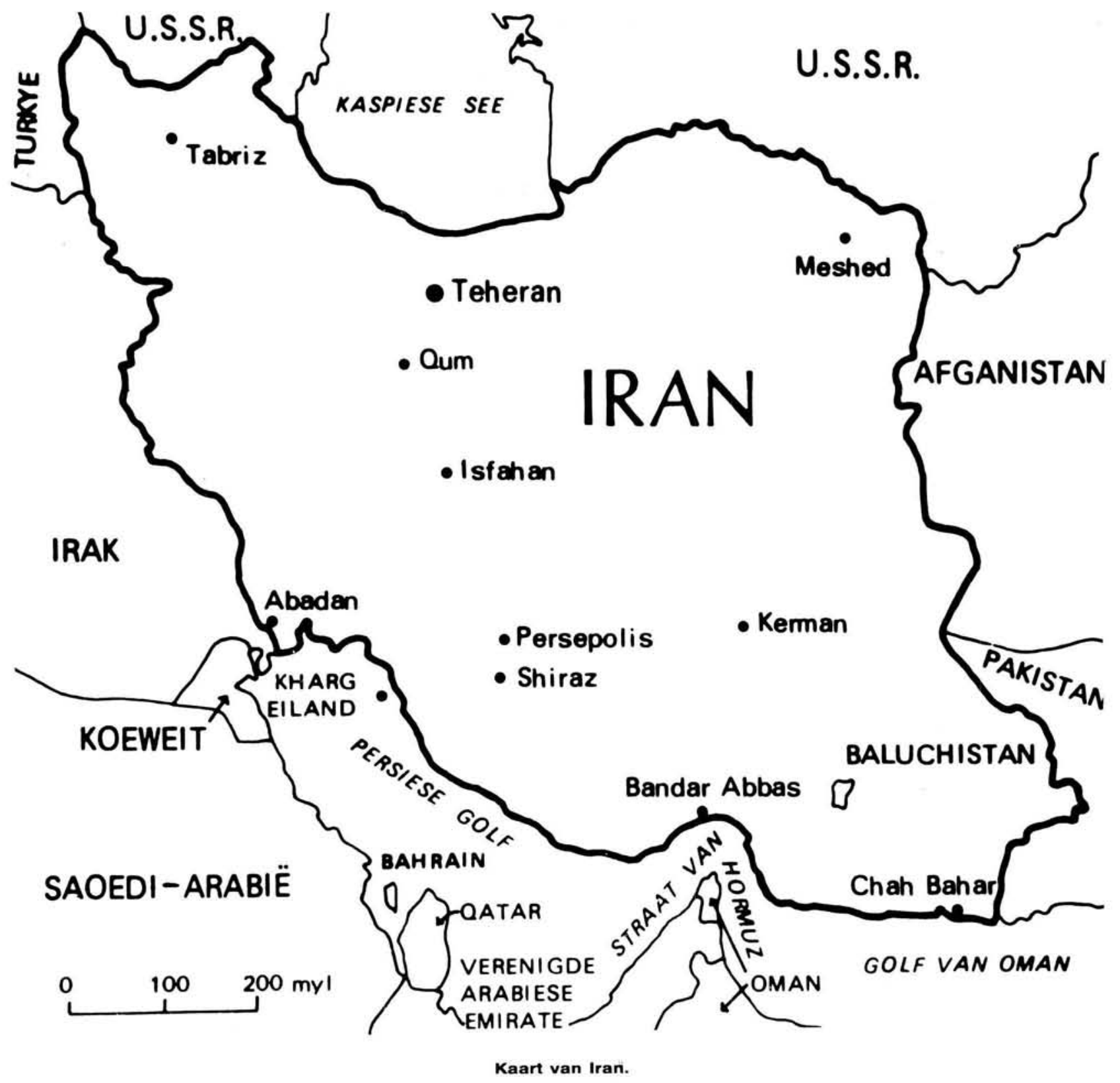




\section{Islam}

Islam is méér as net nog 'n geloof - vir duisende is dit 'n manier van lééf. Daar kan onderskei word tussen die Sunni-Islamiete en die Sjii-Islamiete; $93 \%$ van Iran se bevolking van 35 miljoen is Sjiiete. Sjiisme is aan die einde van die agtiende eeu in Iran aanvaar en as gevolg hiervan het Iran wegbeweeg van die ander Moslemstate en vir die eerste keer sedert die Moslemoorwinning in die sewende eeu 'n politieke eenheid geword.

Islam as godsdiens, het nog altyd 'n skaal van waardes en norme, waarvolgens daar geleef moet word, neergelê. Verder word Islam as die spirituele en sielkundige spil beskou waarom alle kulturele aktiwiteite as satelliete draai.

In die Islamitiese godsdiens en lewensbeskouing word daar nie 'n onderskeid tussen kerk en staat getref nie. Die gewone Islamiet was nie daarvan bewus dat hy aan meer as een gemeenskap behoort nie - Islam was sy hele lewe. Die regeerder of leier is as die skaduwee van God op aarde gesien - dus is absolute kwaliteite aan die regeerder gegee: absolute mag en absolute onderdanigheid aan die heerser.

In die Middeleeuse Persië (Iran), net soos in feodale Europa, was die mag gesetel in die hande van die leenhere. Die Persiese feodalisme verskil egter van die Europese feodalisme daarin dat:

a. die politieke verpligtinge in die Persiese feodale stelsel nie kontraktueel van aard was nie terwyl dié van die Europese stelsel wel was;

b. die Persiese feodale stelsel essensieel vanaf die tiende tot en met die twintigste eeu bestaan het terwyl die Europese feodale stelsel slegs in die Middeleeue bestaan het.

Diefeodale stelsel is deur die Islamitiese leiers (mullahs) ondersteun, want dit vind aansluiting by hulle godsdiensopvattings. In 1906 is 'n konstitusionele regering in Iran in die plek van die Islam ondersteunde middeleeuse feodale stelsel ingestel. Die Iranese konstitusie is op die Westerse grondwet-teorieë gebaseer. In die Weste was daar egter 'n geleidelike oorgang van feodalisme na ' $n$ moderne staatsopset, terwyl dit nie in Iran die geval was nie. Die vroom en godsdienstige Moslem in Iran het homself skielik in 'n morele krisis bevind as gevolg van die skielike verandering wat die Islamitiese geloofsen lewensopvattings onder die invloed van Westerse idees en instellings ondergaan het. Uiterlik is Iran vandag 'n moderne staat maar in wese het die Persiese idee van 'n gemeenskap min verander sedert die Middeleeue.

Met die aanvaarding van Sjiisme en die politieke eenwording in Iran in die agtiende eeu, het ' $n$ nuwe faktor na vore getree: nasionalisme. Daar kan drie tipes nasionalisme, wat mekaar opvolg, onderskei word:

a. die periode tot en met die konstitusionele rewolusie in $1905-6$;

b. die regeringstydperk van Riza Sjah; en

c. die periode ná die Tweede Wêreldoorlog.

Nasionalisme het sy ontstaan te danke aan die groot rol wat die Weste ten opsigte van Iran vertolk het.

In die eerste en dus in die ontstaansperiode van nasionalisme was daar 'n toenemende ekonomiese invloed vanuit die buiteland in Iran te bespeur. Nasir ud- Din Sjah het 'n aantal konsessies aan buitelandse beleggers toegestaan en ook die buitelandse lenings wat aangegaan is, verhoog in ruil vir groter beheer in die administrasie, veral die doeaneadministrasie, deur buitelandse beleggers. Die bevolking het geglo dat hul land aan vreemdelinge gegee word en het dus in opstand gekom. As gevolg van hierdie opvatting het 'n nasionalistiese gevoel ontstaan. Nasionalisme is in terme van die Islamitiese geloof geformuleer en het landswyd inslag gevind. Terselfdertyd het die godsdienstige leiers die bevolking se leiers geword. Stakings en opstande het die regering onder druk geplaas en later laat swig. Die belangrikste aspek van hierdie episode is dat dit aan die religieuse leiers getoon het watter mag hulle het as hulle hul kragte saamsnoer. Nasionalisme in hierdie tydperk was beide anti-korrupsie en anti-buitelands georiënteerd. Beide hierdie aspekte is in terme van Islam geformuleer want alleen hierdeur kon die bevolking oorreed word om die beweging te steun.

Die tweede 'tipe' nasionalisme in die regeringstydperk van Riza Sjah het na vore getree. 'n Kenmerk van hierdie tydperk was die groot mate waarmee die modernisasieproses toegeneem het. Die geïnkorporeerde gemeenskapstruktuur 
in die staat is moedswillig verswak omdat yevoel is dat dit 'n hindernis in die weg van modernisasie is. Die Islamitiese geloof is ook aangeval en die godsdienstige leiers is van alle mag ontneem. Nasionalisme in Riza Sjah se tydperk was dus nie die Islamitiese geloof goedgesind nie want dit was op die Westerse konsep van nasionalisme gebaseer. Riza Sjah het teen die einde van sy regeringstydperk die Duitse staatsopvattings toenemend as die ideale beskou. In navolging van Duitsland het die Sjah die nasionale trots gestimuleer deur voortdurend na die 'glorieryke' verlede van Persië onder die Persiese konings, te verwys. Met Riza Sjah se abdikasie in 1942 het dié droom verbrokkel.

Die derde 'tipe' nasionalisme word in die tydperk wat volg op die Tweede Wêreldoorlog, aangetref. Weer eens is die nasionalisme in terme van die Islamitiese geloof geformuleer. Die voormalige Sjah van Iran was toe reeds aan bewind. Nasionalisme in Iran word hedendaags al hoe meer met die Islamitiese godsdiens geïdentifiseer en die twee kenmerke van die eerste tydperk, anti-korrupsie en anti-buitelands, word weer aangetref. Die religieuse leiers het weer die leiers van die volk geword. Die moskees, die sentra van aanbidding, het nou politieke sentrums geword.

\section{Bevolking}

Die bevolking in Iran is ' $n$ belangrike faktor wat deur beide interne en eksterne groepe in ag geneem moet word. Die Islamitiese geloof en die verskillende 'ismes' (nasionalisme, kommunisme en sosialisme) het 'n merkbare invloed op die bewoners van Iran uitgeoefen. Die vinnige oorgang van 'n feodale stelsel na 'n moderne staatsopset het nie noodwending die bevolking gehelp om ' $n$ beter begrip van hierdie 'ismes' te verkry nie. Inteendeel, het dit die verwarring aangehelp.

Slegs 'n klein persentasie van die Iraniërs is gelettered. Die volgende groepe kan in Iran onderskei word: die regeerders, die geestelikes, die intellektueles, die arbeiders en die nomadiese groepe. Dit is hierdie groepe wat deurslag gee wanneer daar na òf sosialisme òf na kommunisme òf na ' $n$ Westerse georiënteerde demokrasie beweeg moet word.

Die USSR se strateë het dit lankal reeds besef en fyn propaganda gebruik om dié mense se guns te probeer wen, 'n propagandaveldtog wat sedert die uitbreek van die rewolusie verskerp is.
Die intellektueles in Iran kan in twee groepe verdeel word $\mathrm{nl}$ dié wat Westersgesind is en dié wat sosialisme aanhang. Die probleem met die intellektueles is dat hulle alle Westerse of kommunistiese idees sonder meer aanvaar het sonder om te toets of dit voldoende na die res van die bevolking deurgedring het. Daar is sonder meer aanvaar dat indien die oorhoofse strukture geskep is, die res vanself sal kom. Veral die Westers-gesinde intellektueles is ontnugter en het al hoe meer van die Westerse staatsopvattinge begin wegskram.

Dr Erani en sy intellektuele groep het die Marxistiese beweging in Iran begin. Histories kan daar drie stadia onderskei word: die eerste stadium het vanaf die begin van die twintigste eeu tot en met Junie 1920 geduur — hierdie periode kan as die periode van aktiewe sosiale demokrasie in Persië (Iran) beskou word; die tweede fase het van Junie 1920 tot 1941 geduur - tydens hierdie periode veral het die Marxistiese propagandaveldtog sy hoogtepunt bereik; die laaste tydperk het in 1941 met die stigting van die Tudeh-party begin.

Daar is verskeie etniese groepe in Iran van wie die nomade die grootste is. Hulle sluit die volgende belangrike groepe in: die Kurdifaksies; die Turki-stam en die Qashquis. Dit was nog altyd 'n probleem om beheer oor hierdie stamme uit te oefen. Die nomade heg meer waarde aan die sosiale stamstruktuur as aan die staatstruktuur en hul lojaliteit lê dus by die stam. Die belangrikste is die Kurdi-stam wat in die Zagrosstreek aangetref word. Dit is ook bekend dat die Russe met 'n voortdurende propagandaveldtog onder die Kurdistam aan die gang is. Die sogenaamde griewe wat hulle teen die Iranese, Arabiere en Turke koester, word gedurigdeur aangeblaas. Die Russe buit ook die onvergenoegdheid uit wat tussen die Nomade oor die verdwyning van die feodale stelsel heers - die kommunistiese idee van gemeenskaplike grondbesit is uiteraad vir hulle baie aanvaarbaar. Dit skyn dus dat hulle, hoewel afgesonder, tog 'n baie belangrike rol kan speel in die ommeswaai van een ideologie na ' $n$ ander. Die Kurdistam se strewe na 'n eie onafhanklike republiek, wat nuwe lewe ingeblaas is en na verwagting ' $n$ faktor sal bly waarmee rekening gehou moet word, kan politieke onrus in Iran vir 'n lang en opbeperkte tydperk laat opvlam. Orals teen Iran se grense word ook nomadiese groepe aangetref - 'n baie onstabiele faktor wat nie gering geag mag word deur die Weste nie want die nomade is baie ontvanklik vir kommunisme. 


\section{Iran in die internasionale magstryd voor 1979}

\section{Buitelandse beleidsformuleringsproses in Iran}

The importance of a universal, intercontinental understanding and association is in no way diminished by the assertion that geography continues to remain the most important single factor in the formulation of a country's foreign policy.

Die na-oorlogse buitelandse beleid van Iran word gekenmerk deur sy sikliese gang. Eerstens is ' $n$ beleid van alliansie verwerp, daarna is dit tog in die volgende periode aanvaar; tydens die regering van Sjah Pahlavi was dit 'n de facto beleid van onverbondenheid wat binne 'n raamwerk van pro-Westerse gesindheid gevolg is. Iran se buitelandse beleid was nog altyd gevoelig vir gebeure elders in die internasionale sisteem, veral ten opsigte van die Persiese Golfgebied en die Indiese oseaan.

Die tydperk voor 1953. In hierdie tydperk is 'n poging aangewend om 'n balans tussen die teenstrydige aspirasies van die betrokke magte (Brittanje, USSR) te handhaaf. Daar is ook meer op die hulp van internasionale organisasies en die VSA staatgemaak in 'n poging om 'n houding van onverbondenheid in die internasionale politieke stelsel te handhaaf.

Die tydperk 1953 - 1963. 'n Meer proWesterse houding is ingeneem. Die sekuriteit van die Sjah se régime en dié van die staat is as een geïdentifiseer en sodoende is optrede bepaal. Daar is verwag dat die buitelandse beleid beide die eksterne en interne faktore, om die stabiliteit en voortbestaan van die Sjah se regime te verseker, sal versterk. Dus is daar na eksterne militêre steun ten gunste van bogenoemde idees gesoek.

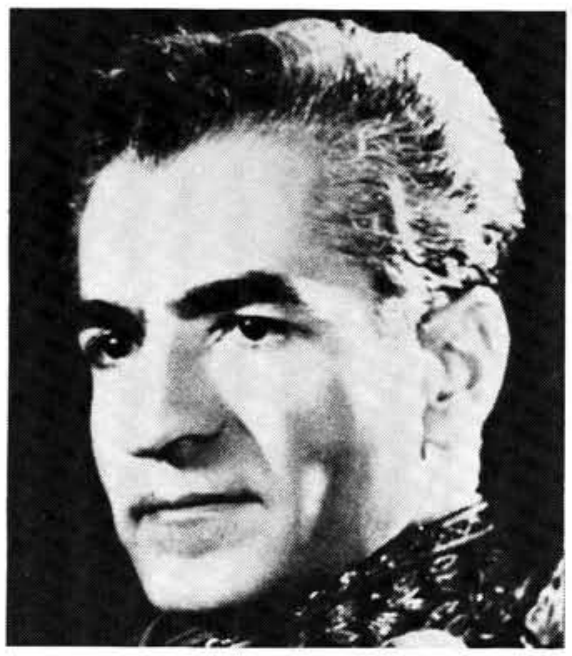

Shah Reza van Iran

(Foto: Press Association)
Die tydperk 1963 en daarna. Die proWesterse houding het begin afkoel. Intern het daar 'n hele aantal belangrike veranderinge plaasgevind in die vorm van sosio-ekonomiese hervormings. Iran se ekonomiese ontwikkeling het 'n groot stukrag gevind in die toenemende inkomste' wat olie meegebring het. In 1963 het die Sjah sy sogenaamde 'Wit Rewolusie' of 'Sjahen volksrewolusie' geïnisieer in 'n poging om die moderniseringsproses te verhaas. In 1965 is Iran se beleid van onverbondenheid ná die Tweede Kadmir-oorlog beklemtoon. Die Sowjet-Unie het die rol van bemiddelaar tydens dié oorlog vertolk en Iran het onder die indruk gekom dat die USSR nou slegs 'n status-quo-moondheid is. As gevolg van hierdie waninterpretasie het die Iranese beskouing van en houding teenoor die internasionale politieke sisteem 'n aansienlike verandering ondergaan in die middel sestigerjare. Daar is geglo dat die intensiteit van die bi-polêre sisteem, wat as gevolg van die Koue oorlog ontstaan het, verminder het; dat die Russiese imperialistiese neigings nie langer vir Iran en Turkye gevaar inhou nie omdat die USSR as 'n status-quo-moondheid meer selektief ten opsigte van sy objektiewe geword het.

Sjah Mohammed Reza Pahlavi was hoofsaaklik verantwoordelik vir die formulering van die buitelandse beleid. Die Sjah se absolute heerskappy is hierdeur bevestig. Daar bestaan geen formele beleidsformuleringsproses soos dit in die Westerse state aangetref word nie. Verder word daar ook nie belangegroepe, wandelgangpolitici of massamedia, wat enigsins die buitelandse beleidsformuleringsproses kan beïnvloed, aangetref nie. Die sosiale waardesisteem in Iran is en word steeds deur interne sowel as eksterne groepe as 'n faktor beskou wat die buitelandse verhoudinge wil beperk. Die Minister van Buitelandse Sake in die vroeë sewentigerjare het sy rol soos volg omskryf: I am honoured to be executing Iran's foreign policy. The Imperial Government's overall policies are worked out by the Shahanshah. He decides the principles, all the broad outlines. We carry out his policies to the best of our abilities.

As gevolg van die houding van binnelandse opponente en dié van die VSA en die USSR teenoor Iran het die Sjah sy buitelandse beleid só geformuleer dat dit nie daaruit kon blyk dat hy hom openlik by een van die moondhede geskaar het nie. Daar het geen wisselwerking van insette en uitsette tussen die binnelandse en buitelandse beleid van Iran bestaan nie. Die interne 
faktore wat ingewerk het op die Sjah se formulering van buitelandse beleid was die heersende sosiale waardesisteem, die geestelike element en die feit dat Iran oor beperkte mannekragvermoëns beskik. In hierdie opsig was die land se militêre slagvaardigheid 'n uitsondering.

Met die uitbreek van die Iranse revolusie en die afkondiging van krygswet in Augustus 1978, het die Sjah as die hoogste gesagspersoon in sy land, bevel gevoer oor die grootste oorlogsmasjien buite die VSA, Rusland en Europa. Hoewel die gesamentlike gevegsmagte kwalik 410000 man oorskry het, was die Sjah se affiniteit vir wapentuig daarvoor verantwoordelik dat Iran 'n indrukwekkende arsenaal van diverse gesofistikeerde wapenstelsels opgebou het. Dit het oa bestaan uit lugafweerstelsels met Amerikaanse Hawk grondlugmissiele toegerus; ongeveer 1470 tenks; Tow en Dragon geleide tenkafweermissiele; ongeveer 710 artilleriestukke en 440 selfaangedrewe grofgeskut; en 460 vegvliegtuie wat 'n groot aantal 4FD/F4E Phantoms en F14A Tomcats ingesluit het. Die land se verdedigingsbegroting vir 1978/79 het 9,94 biljoen dollar bedra, dit ongeveer 13 persent van die bruto volksproduk.

Die fenomenale uitbouing van die Iranse weermag gedurende die afgelope 20 jaar is deels toe te skryf aan Iran se geopolitieke ligging veral wat sy gemeenskaplike grens met Rusland betref.Nietemin het die Sjah se militêre beheptheid ook 'n rol gespeel, en Theodor Sorensen, 'n raadgewer van pres Kennedy, kon tereg verklaar: The Shah insisted on our supporting an expensive army too large for border incidents and internal security and of no use in all-out war. Ironies genoeg getuig Sorensen se woorde van profetiese kortsigtigheid, want tydens die Iranse revolusie het die weermag, wat aanvanklik probeer het om die opstand te onderdruk. geswig en as 'n eertydse nasionale instelling feitlik verbrokkel. Dit het oa gelei tot die onttrekking van Iranse troepe uit Oman wat implisiet op ' $n$ ommekeer in Iran se buitelandse beleid mbt sekerheid in die Persiese Golf en sommige van sy buurstate dui.

\section{Iran as 'n regionale moondheid}

A country should have an international policy in order to develop a regional one.

- Amir Taheri

Iran se onmiddellike buurstate is Afganistan, Pakistan, Verenigde Arabiese Emirate, Qatar,
Saoedi-Arabië, Koeweit, Irak, Turkye, Dubai, Bahrain, Abu-Dhabi, Oman en die USSR. Sy primêre oogmerk, regionaal beskou, was gedurende die Sjah se bewind, om vrede, stabiliteit en vooruitgang in die strategiese Persiese Golfgebied te bewerkstellig. Behoefte aan sekuriteit in dié gebied was die bepalende faktor wanneer buitelandse beleid ten opsigte van die buurstate geformuleer is. Die Sjah het noemenswaardige vordering op die regionale verhoudingsvlak gemaak. 'n Ander baie belangrike faktor wat inwerk op Iran se regionale beleidsformuleringsproses is die internasionale magsbalansstelsel.

Nadat Brittanje hom finaal aan die Persiese Golfgebied onttrek het, het Iran die leemte probeer vul. Dit was reeds vóor die Britse onttrekking 'n ideaal van Iran om dié leierskapsposisie te beklee. Die Sjah het egter reeds vóor die Britse onttrekking van sy mikpunte in die Golfgebied gerealiseer. Brittanje wou 'n 'Federasie van Nege' stig maar Iran het hom hierin teengegaan. Die 'Federasie van Nege' sou uit Bahrian, Qatar en die sewe ministate van die Verdragskus bestaan.

Iran het in 1971 sy gesag oor Abu Musa en die twee Tumb-eilande herstel. Irak het as gevolg hiervan sy betrekking met Iran verbreek. Iran het Abu Musa en die Tumb-eilande sedertdien in militêre basisse omskep. Vanaf hierdie basisse word beheer oor die strategiese Straat van Hormuz uitgeoefen.

Die Sjah het die veiligheid van die Persiese Golf op die hart gedra selfs nog voor die Britse onttrekking. In 1969 het hy die volgende voorgestel: We would be willing, in conjunction with Sa'udi Arabia, to provide protection for the Gulf States. Our paratroop and armored regiments at Shiraz can give them as much protection as the British forces in the area today ... We would like to see a common defence policy established for the area. We would propose that the Persian Gulf become a closed sea, and that the port of Bahrayn be used as a joint base.

Iran en Afganistan handhaaf steeds ekonomiese betrekkinge ofskoon dié twee lande se tradisionele vriendskapsbande ietwat vertroebel is deur die val van die Daoud-regering in Februarie 1978. Afganistan se huidige regering het dmv kommunistiese steun aan bewind gekom en die feit dat Iran ná die val van die Sjah in 'n toenemender mate 'n anti-westerse houding begin inneem het, kan opnuut ' $n$ versoening met 
Afganistan bewerkstellig. Maar die interne politiek van Afganistan, ten beste onbepaalbaar, bly 'n deurslaggewende faktor.

Onder die bewind van die Sjah het Iran Turkye, wat uiters strategies geleë is, as 'n belangrike bondgenoot beskou in soverre dat hierdie alliansie verhoed het dat Iran algeheel deur die USSR geïsoleer word. Maar die bewind van Bulent Ecevit, wat in Februarie 1978 'n nuwe regering in Turkye tot stand gebring het, is tot dusver gekenmerk deur politieke en sosiale onrus en alles dui daarop dat Ecevit in die Sjah se voetspore kan volg. Die Turkse regering moes noodgedwonge krygswet in sy Kurdiese Provinsies, waar Marxistiese groepe hul ingegrawe het, afkondig. Die feit dat beide lande op die oog af 'n konsensus handhaaf wat die Kurdiese opstandelinge betref, is egter nie genoeg om 'n bestendige verband daar te stel nie. Turkye se lidmaatskap van NAVO impliseer noodwendig 'n opsigtelike verwydering tussen hierdie lande, dog dit is interessant om daarop te let dat Turkye sedert Julie 1978 ernstige pogings aangewend het om ' $n$ beleid van onverbondenheid na te volg. Toestande in Iran en Turkye vertoon merkwaardige ooreenkomste en 'n oorname deur 'n regering wat meer ontvanklik teenoor die kommunistiese blok staan, kan Westerse en veral Amerikaanse belange in dié gebied ernstig skaad.

Iran en Irak - tradisionele aartsvyande - het in 1975 begin met samesprekings maar tydens die laaste jare van die Sjah se bewind het die hoop op nouer samewerking en kollektiewe sekerheid skraal gebly. Die onrus in Iran wat die val van die Sjah voorafgegaan het, het die hoop in Irak laat opvlam dat laasgenoemde met die steun van die Sowjet-Unie beheer oor die Persiese Golf te verkry. Resente gebeure in Irak soos oa die vervolging van plaaslike kommuniste van wie 'n aantal dmv ' $n$ klandestiene operasie gered en na die USSR geneem is, het betrekkinge met Rusland vertroebel. Van groter belang is egter die dreigende burgeroorlog in Irak wat ontketen is deur die Islamitiese Sjias, (Shi'tes) Irakese volksgroep wat deur die stigting van 'n Islamitiese republiek in Iran aangevuur is om ' $n$ soortgelyke bedeling in die suidelike provinsies van Irak te skep. Dié verloop van sake het noodwendig die kanse op beter betrekkinge tussen Irak en Iran benadeel.

Saoedi-Arabië, ook een van die oliereuse in die Midde-Ooste, het net soos Iran, ook hulp aan die Sultan van Oman verleen tydens sy stryd teen die Dhofar-rebelle. Nietemin kon die verhoudinge tydens die Sjah se bewind nie genormaliseer word nie - Iran het eienaardig genoeg Saoedi-Arabië se vriendskapsbande met die VSA herhaaldelik gerepudieer terwyl Irak afsydig gestaan het oor die goeie betrekkinge tussen Iran en Israel. Wat laasgenoemde verbond betref, het Iran se totale breuk met Israel en sy ondersteuning van die Arabiese ideaal 'n gunstige klimaat vir beter verhoudinge met Saoedi-Arabië geskep, veral na laasgenoemde se breuk met Egipte.

Betrekkinge tussen Iran in Koeweit, wat saam met eersgenoemde en Saoedi-Arabië dié belangrikste olieprodusente in die Midde-Ooste uitmaak, is nie wesenlik beinvloed nie. Insgelyks het Iran se verklaarde ondersteuning van die Arabiese saak daartoe bygedra dat bestaande betrekkinge met Bahrein, Qatar en Abu Dhabi in stand gehou kon word. Nietemin is hierdie Golfstate, wat voorheen die militêre beskerming van die Sjah geniet het, nou blootgestel aan eksterne aanslae.

Beide Iran en Oman begrens die straat van Hormuz wat van strategiese belang is omdat 50 persent van die wêreld se olietenkskepe deur hierdie seeweg beweeg. As gevolg van die USSR se pogings om beheer oor Oman te verkry, het Iran in die verlede as beskermheer vir dié staat opgetree.

\section{Iran as 'n internasionale moondheid}

Iran is nou meer as ooit vantevore ' $n$ belangrike faktor in die internasionale magstryd en het dus 'n wesenlike behoefte aan interne sowel as eksterne sekuriteit. Gedurende die laaste weke van die Sjah se bewind was van interne sekerheid haas geen sprake nie en die disintegrasie van die grondmagte het die tussentydse regering van dr Bazarghan se taak om binnelandse orde te herstel, feitlik onmoontlik gemaak.

As internasionale moondheid het Iran se posisie ' $n$ radikale verandering ondergaan. Tradisioneel het sy buitelandse beleid sentreer om die beveiliging en beskerming van die Persiese Golf, die Straat van Hormuz en die Arabiese See. 'n Bykomende dimensie was die strewe om die Indiese Oseaan van mededinging tussen die Sowjet-Unie en die Weste te vrywaar. Gevolglik het Iran 'n beleid van onverbondenheid gevolg. Dit blyk duidelik uit die volgende verklaring deur die Sjah in 1975: We don't mix oil with politics. We sell oil to oil companies and they take it where they want. 


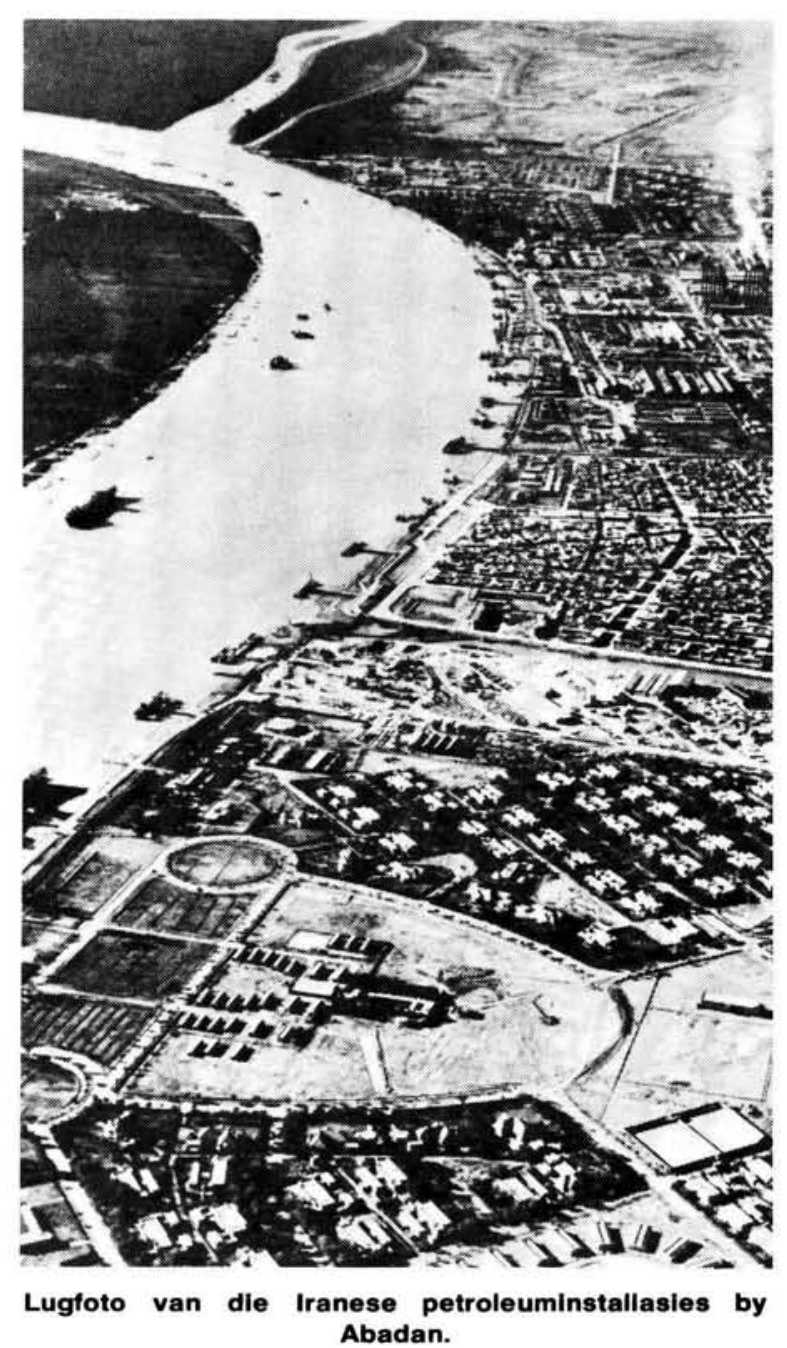

In teenstelling hiermee is die huidige regering passief en verkeer trouens nie meer in 'n posisie om as bewaker van die Golfstate se belange op te tree nie. Soos politieke waarnemer Shahram Chubiu dit gestel het: Whatever the new regime. its policies will be less favourable to Western interests than before: it will be politically non-aligned, militarily and diplomatically passive, militant on oil prices and conservationist in production policy.

Ten einde Iran se posisie in die internasionale magstryd in reliëf te stel, moet beurtelings na dié land se verhoudinge met Brittanje, die VSA en Rusland gekyk word.

Brittanje was jare lank die enigste groot moondheid wat militêre basisse in die Indiese Oseaan gehad het. Sy politieke en militêre onttrekking aan die gebied in 1971 is voorafgegaan met ' $n$ ooreenkoms met Iran. Laasgenoemde het op sy beurt in ' $n$ poging om beheer oor die gebied te bevestig, in November daardie jaar die strategiese eilande Abu Musa en die twee Tumb-eilande beset. Hierdeur het Iran, wat beheer oor die straat van Hormuz verkry het, 'n belangriker rol in die internasionale magstryd begin vertolk hoewel Brittanje steeds lug- en vlootbasisse op die eiland Masirah naby Oman besit het.

Die VSA het sedert die Tweede Wêreldoorlog vriendskapsbande met Iran gehandhaaf. Dié tydperk van samewerking het 'n aanvang geneem toe die VSA ingegryp het om ' $n$ Russiese besetting van Azerbaijan, 'n noordelike provinsie van Iran, te beëindig. Die VSA was nog altyd bewus van die USSR se begeerte om toegang tot die ysvrye hawens van die suide te verkry veral ná die ontdekking van die olievelde aan die Persiese Golf. Tydens die Sjah se bewind is die Amerikaners toegelaat om oa militêre installasies in Iran in stand te hou waarmee Russiese troepebewegings gemonitor kon word en die Sjah kon op sy beurt haas elke wapenstelsel van sy keuse in die VSA bekom.

Die val van die Sjah het ook die einde van hierdie era beteken. Die nuwe bewind het ' $n$ aanvang geneem met anti-Amerikaanse betogings wat oa gepaard gegaan het met die besetting van die Amerikaanse Ambassade in Teheran in Februarie. Maar die gestadigde vervreemding tussen die VSA en Iran kan teruggevoer word na 1978 toe eersgenoemde verval het in ' $n$ inkonsekwente en teenstrydige beleid tov sy betrekkinge met Iran. Washington was kwalik meer as 'n belangelose toeskouer van die Iranse revolusie, waarskynlik vanweë sy toenemende isole. rende beleid en die onvermoë van sy inligtingsdienste om toestande in Iran reg te interpreteer. Die VSA se onwilligheid orn regstreeks in te gryp en die situasie ten gunste van die Sjah te beredder, kon egter nie voorkom dat die nuwe regeerders in Iran Washington herhaaldelik repudieer oor sy verbintenis met die afgesette Sjah nie. In Mei 1979 het een van Iran se geestelike leiers, Ali Akbar Rafsanjani, byvoorbeeld beweer dat die VSA verantwoordelik gehou moes word vir die dood van elke Iranees wat in die revolusie omgekom het. ' $n$ Resolusie van die Amerikaanse Senaat waarin die summiere teregstellings van voormalige aanhangers van die Sjah afgekeur het, kon slegs 'n detrimentele uitwerking op die verswakkende betrekkinge tussen die VSA en Iran hê. Ofskoon die VSA nog onbepaald lank ' $n$ houvas op Iran sal hê wat die onderhoud en vervanging van onderdele van wapentuig betref, kan verwag word dat laasgenoemde voortaan doelbewus sal 
poog om sy afhanklikheid van die VSA sover moontlik te verminder.

Strategies beskou, was die val van die Sjah 'n gevoelige terugslag vir die Weste en veral die Verenigde State. Dit bring mee dat in die geografiese gebied wat die Golfstate omsluit, 'n magsleemte gelaat is wat in die lig van die heersende energiekrisis, Westerse belange op haas elke terrein in 'n dilemma met verreikende implikasies geplaas het. Die verwydering van Amerikaanse betrokkenheid het dan ook feitlik (en nie toevallig) saamgeval met hernieude pogings aan die kant van die Sowjet-Unie om $\mathrm{dmv}$ sosialistiese groepe in Iran onregstreeks die magsleemte wat deur die pro-Westerse regering van die Sjah nagelaat is, te vul.

\section{USSR. Die USSR se oogmerke ten opsigte van} Iran kom duidelik na vore soos dit deur $\mathrm{K}$. Troyanovsky gestel is: The importance of Persia for the creation of the Oriental International is considerable... The best friend of the Persian people is proletarian Russia, . . Revoluntionary Russia is the sincere and disinterested inspiration of Persia, a precious counselor, a guide worthy of confidence to orient her towards democracy ... If Persia is the door through which one has to go in order to invade the citadel of the Revolution of the Orient, That is to say India, we must forment the Persian revolution . . . The Persian uprising will be the signal for a series of revolutions that will spread through all of Asia and part of Africa. A political situation favourable to democracy in Persia has an extraordinary importance for the emancipation of the entire Orient ... All that is needed is an impulse from the outside, an external aid, an initiative, and a resolute decision. This impulse, this initiative, this resoluteness, can come from our Russian revolutionaries through the intermediary of the Russian Moslems.

Dit was in 1918 en nou in 1979 is die USSR nog dieselfde mening toegedaan, hulle is selfs ernstiger as ooit tevore want 62 persent van die wêreld se olie is nou ter sprake.

Die gesamentlike grens wat Iran en die USSR deel, beslaan 2500 kilometer. As een van Iran se grootste handelsvennote het die USSR nog altyd sy gas goedkoop van Iran af verkry terwyl hy sy eie teen hoër markpryse verkoop het en sal dus alles moontlik doen om die situasie te handhaaf. Indien die USSR beheer oor die Indiese Oseaan en die Persiese Golf kan verkry, kan hy die lewensbelangrike olievoorrade wat bestem is vir die NAVO-lande, Japan en die VSA afsny.

In die sestigerjare het die Kremlin begin om sy beleid ten opsigte van Iran in terme van dié land se binnelandse hervormings aan te pas. Die Russe het besef dat die strukturele verandering in Iran 'n noodwendige vervreemding van 'n sekere deel van die bevolking teenoor die Iranese regering gaan meebring. Hulle het ook ingesien dat hulle steun onder die ontevrede anti-Sjah groep wat linkse studente, groot landeienaars, fanatiese geestelikes en separatistiese stamme insluit, kon werf. Gevolglik is in 'n toenemende mate gepoog om Iran van die Weste te vervreem. Daar is byvoorbeeld beweer dat die Westerse maatskappye olieproduksie laag hou omdat die Westerse moondhede ' $n$ ekonomies onderontwikkelde Iran as voorsiener van grondstowwe wou behou en terselfdertyd hul nywerheidsprodukte daar wou bemark. Baie Iranese het dit dan ook geglo en verder teen die Weste gedraai. Olie is egter een van die belangrikste redes waarom die USSR graag 'n kommunistiese bewind in Iran sou wou sien. Iran besit die reusagtige Abadanraffinadery en dié is teenaan die kus geleë en is ook met 'n kushawe verbind. Indien die USSR beheer oor Iran kan verkry, sal hul dan makliker beheer oor Khargeiland, die wêreld se grootste olieterminus, kan verkry. Die Russe sal dan ook 'n ideaal kan verwesenlik - 'n direkte deurgang na die Arabiese See en die Indiese Oseaan.

Veelal word die strategiese belangrikheid wat die olieproduserende lande aan die Persiese Golf vir die Weste en die Sowjet-Unie inhou, vertolk in terme van die energiebehoeftes van die VSA en sy Westerse bondgenote. Hierdie benadering is gegrond op die aanname dat die Sowjet-Unie en sy satelliete wat die onmiddellike toekoms betref, tov olie en gas selfvoorsienend is. Hieruit volg die veronderstelling dat die USSR se belangstelling in en betrokkenheid by die jongste verwikkelinge grootliks neerkom op 'n strewe om beheer te verkry oor hulpbronne wat vir die Weste onontbeerlik is.

Die Sowjet-Unie se toetrede tot die 'oliepolitiek' berus egter ook op die besef dat sy eie oliereserwes nie ad infinitum onafhanklikheid van eksterne bronne sal verseker nie. Reeds in November 1977 het die Russe amptelik te kenne gegee dat probleme met.die lewering van olie aan Oos-Europa binne die bestek van drie jaar ondervind sou word. Dit is interessant om daarop te let dat brandstofpryse in die USSR tussen Oktober 1977 en Maart 1978 met 90 persent 
verhoog is. In 1978 is ' $n$ landwye brandstofbesparingsprogram in Rusland van stapel gestuur — enigsins ' $n$ betekenisvolle aanduiding dat die toenemende binnelandse vraag groter druk op die produksievermoë van dié moondheid se ontginningsnywerheid uitoefen. Volgens Westerse inligtingsbronne gaan dit nie soseer oor die beskikbaarheid van reserwes nie, maar eerder om geografiese belemmeringe en die tekortkominge van Russiese ontginningsmetodes. Wat eersgenoemde aspek betref, blyk dit dat ' $n$ groot deel van die Sowjet-Unie se oliereserwes, wat onder ' $n$ bevrore tundra van tot 500 meter diep weggesluit lê, vanweë die Russe se verouderde boortegnieke nie ontginbaar is nie. In dié verband kan genoem word dat die Russe nog grotendeels gebruik maak van 'n metode waarvolgens water in die oliestratum gepomp word om 'n opwaartse druk van ru-olie te verseker; een nadeel hiervan is dat die water mettertyd deur die oliehoudende laag ontsnap en agv die drukverlies is voortgesette ontginning nutteloos.

Ten einde hierdie probleem op te los, het die Sowjet-Unie gedurende die afgelope paar jaar begin om gesofistikeerde boortoerusting by die VSA te koop. Dit is egter nie genoeg om die huidige tempo van nywerheidsontwikkeling in die USSR te verseker nie en dié moondheid kan teen 1983/84 reeds ' $n$ ernstige energiekrisis ondervind, aldus ' $n$ bevinding van die Amerikaanse Central Intelligence Agency. Dit lê dus voor die hand dat die Kremlin in sy soeke na alternatiewe bronne vroegtydig langs diplomatiese en politieke weë sal poog om gunstige toestande ter verkryging daarvan te skep.

Die USSR het nog voor die hervormings van die sestigerjare ' $n$ aanvang gemaak met ' $n$ propagandaveldtog wat op die flaters van Westerse oliemaatskappye gemik was. Die USSR se belang in Iran het ook vergroot vanweë die vrees wat ontstaan het dat China ekspansionistiese strewes mag begin toon en in ' $n$ toenemende mate ' $n$ groot moondheid kan word. Die USSR het in 1968 begin om met gereelde tussenposes sy skepe die Indiese Oseaan in te stuur. Inmiddels het China sy gewilligheid om Iran te help en sodoende die veiligheid van die Persiese Golf te verseker, te kenne gegee.

Die USSR het tot dusver nog altyd van indirekte middele gebruik gemaak om Iran se ondergang te probeer bewerkstellig. ' $n$ Voorbeeld hiervan is die houding van Afganistan teenoor Iran. Afganistan het in ' $n$ toenemender mate ' $n$ sentrum vir anti-Iranese optrede geword. Die volgende is gebeurtenisse wat in 1978 plaasgevind het: (1) Die Minister van Buitelandse Sake van Afganistan bring ' $n$ besoek aan Iranese terroriste in Kuba en beloof hulp aan hulle; (2) Afganese agente sypel Iran binne via Indië en Pakistan. Hulle neem deel aan sabotasie bedrywighede in Iran; (3) Die opening van Sowjet-beheerde opleidingskampe in Mazar Sharif in noordelike Afganistan. Marxistiese indoktrinasie en guerilla-opleiding word hier verskaf aan rekrute wat uit Iran, die Arabiese state en die noord-westelike provinisies van Baluchistan kom.

Uit die Iranese geskiedenis blyk dit duidelik dat die USSR in die verlede nie geskroom het om betrokke te raak by rewolusionêre geweld in Iran nie. Voorbeelde hiervan is die Russiese betrokkenheid in die Gilanprovinsie (1919 en 1953), in die Kurdiese gebied, Mehabad, in 1946 en in Azarbaijan (1920 en 1945).

\section{Iran en die toekoms}

Iran se posisie in die internasionale magstryd in die huidige tydsgewrig is, om die minste daarvan te sê, uiters delikaat. Dit kan trouens gestel word dat die moontlike oorgang van hierdie land (wat steeds poog om 'n vorm van neutraliteit te prakseer) na die kant van of die Weste of die Kommunistiese Blok die magsbalans merkbaar sal beïnvloed. Bepalende faktore in die heersende omstandighede blyk veral op die terrein van interne geskille geleë te wees ofskoon die invloed van eksterne kragte nie buite rekening gelaat kan word nie. In dié verband bly dit ' $n$ ope vraag of die anti-Sjah groepe in die buiteland die huidige regering sal steun of gaan poog ' $n$ ander vorm van regering at te dwing. Dieselfde geld vir faksies binne die plaaslike bevolking.

Die Islamitiese leerstelling, ijtihad (die reg van intelligente beredenering) en die beginsel ijma, (die reg van Moslems om hulself te regeer), kan nog ' $n$ basis verskaf, vir liberale en demokratiese ontwikkeling in Iran. Die linkse groepe in Iran het byvoorbeeld beweer dat die Islamitiese geloof nie teen Sosialisme gekant is nie.

Die moontlikheid dat Iran ' $n$ sosialistiese staat kan word, is groot. Sekere idees van die sosialistiese ideologie stem ooreen met die Islamitiese geloof soos byvoorbeeld die beginsel dat die eienaarskap van produksiemiddele by die gemeenskap as geheel moet berus en dit 
tot voordeel van almal geadministrateer moet word. Die klem val gewoonlik op die stoflike behoeftes en die fisiese geluk van die bevolking.

Die huidige bewind van Khomeini verseker nie noodwendig vooruitgang en stabiliteit vir Iran nie. Die onsekerheid wat die onewewigtige oorgang van 'n tradisionele na 'n moderne kultuur meebring is nog nie uitgewis nie. Die Iranese bevolking is nog nie behoorlik daartoe in staat om beheer oor sy maatskaplike en fisiese omgewings uit te oefen nie. Verskeie krisisse wat moontlik mag ontstaan is ten opsigte van (1) nasionale identiteit; (2) politieke legimiteit; (3) penetrasie van die gesag van die sentrale regering; (4) deelname van die bevolking en (5) distribusie van regeringsmag om ekonomiese groei en mobilisasie van hulpbronne te verseker. Meeste van hierdie krisisse het bygedra tot die ongewildheid en val van die Sjah - hy het hulle oor die hoof gekyk. As gevolg van 'n onvoldoende integrasieproses tussen staat en gemeenskap het 'n mens ten opsigte van Iran 'n staat-nasie in plaas van 'n nasiestaat gevind. Hierdie wanverhouding in Iran kan veroorsaak dat die USSR se ideologiese deskundiges hierin 'n kans sien om verdere chaos te saai in Iran.

Daar word ook gereken dat die Islamitiese Republiek van Khomeini dalk slegs 'n oorgangsfase is voordat 'n pro-Sowjet régime oorneem. Dié régime sal dan òf op die Khadaffi ò die Adeni-model gebaseer wees. Die USSR is nie van plan om Iran aan die Weste oor te laat nie. Indien die USSR beheer oor Iran kan verkry, kan hy ook moontlik lateraan beheer oorneem in Saoedi-Arabië, Koeweit en die kleiner Golfstate. In November 1978 was daar 500000 Afganese wat onwettig in Iran gebly het. Meeste van hulle is arbeiders. Die Russiese invloed in Iran is dus sterk veral onder die werkers. Kanouri, leier van die Tudeh-party, het alreeds gesê dat die olie-werkers slegs opdragte van hom uitvoer. Dus het die USSR alreeds 'n stewige houvas op die belangrike oliebron in Iran.

Die rewolusionêre toneel het die beslissende arena geword vir die konflik tussen die Weste en die Kommunistiese lande. Die val van die Sjah en sy regering in Iran is die grootste beleidsmislukking van die VSA in die buiteland. Carter se onvermoë om die situasie na regte te begryp en handellend op te tree, sy beheptheid met menseregte het die VSA in die oë van die wêreld 'n neerlaag laat lei. Die skuld lê egter ook by Carter se raadgewers. Hulle het die krag van die Iranese rebelle onderskat en terselfdertyd die vermoë van die Sjah om aan bewind te bly oorskat. Waar Carter se voorgangers sterk standpunt ten opsigte van die Persiese Golf ingeneem het, het hy huiwerig voorgekom. Deurdat Iran heeltemal anti-VSA gedraai het, het die Weste van sy belangrikste inligtingskantore verloor. Inligting wat in Iran oor die omliggende lande ingesamel is was altyd van groot hulp by die SALT-samesprekings.

Die Weste het nou ook die grootste koper van sy wapens verloor. Die lande wat die slag die meeste voel is die VSA, Brittanje, Duitsland en Frankryk. Die VSA het verskriklik bontgespring met sy erkenning van eers die Sjah se régime, toe die Baktiar-regering en nou die regering van Khomeini. Die VSA gee dus nou erkenning aan die rewolusionêre metode om magspolitiek te verkry. Saoedi-Arabië en Turkye as kwesbare state in daardie gebied glo nie meer in die VSA nie en tensy daar drastiese stappe deur die Carter-administrasie gedoen word om die vertroue te herstel, mag die twee lande dalk na die kommunistiese lande vir hulp draai. Daar word alreeds anti-VSA uitsendings uit die USSR na Iran gestuur.

Khomeini kon in daardie stadium nog daarin slaag om hulle teë te gaan soos toe hy die Fedayeen-opstandsbeweging se lede (almal kommuniste) as vyande van die Moslem-geloof bestempel het. Of dit altyd gaan slaag, is ' $n$ ander saak. Faktore wat teen hom kan werk is die feit dat die Iranese heel waarskynlik sekere Westerse gebruike sal wil behou, soos oa die vryheid wat die vroue verkry het. Iran kan nie weer in 'n voorontwikkelde staat verander word nie maar daar kan net gehoop word dat die Moslem-geloof die kommunisme kan teëhou. Khomeini se weiering om polisieman van die Persiese Golf te speel maak sake makliker vir die Russe. Die Weste sal dus hier hard aan 'n plan moet dink. Khomeini se isolerende houding kan dalk in hierdie stadium tot voordeel van die Weste strek sodat hy sy strategiese ideale kan bepaal. Die Iranese vriendskapsbande met die Palestynse Bevrydingsorganisasie kan bevraagteken word en dit voorspel niks goeds vir die Weste nie.

Die Weste en veral die VSA, sal nou hard daaraan moet werk om die Russiese inmenging in Iran te beëindig. Alleen as Iran 'n onverbonde land bly kan die huidige magsbalans nog bestaan. Indien die USSR beheer oor Iran verkry, mag hy dit uitbrei tot die Arabiese gebied. Die USSR sal dan toegang hê tot die ysvrye hawens en die wêreld 
se belangrikste olie- en seeroetes. Uit 'n militêr-strategiese oogpunt gesien, is die feit dat die USSR dan beheer oor die Indiese Oseaan sal hê, eweneens belangrik.

Iran is vandag en in die jare wat kom die brandpunt op die internasionale terrein. Alle politieke en militêr-strategiese beleide sal in terme van Iran geformuleer word. Behalwe die Weste en die USSR, kan China ook 'n groot rol ten opsigte van Iran vertolk.

\section{Historiese kronologie}

26 Okt 1919 Mohammed Reza, huidige Sjah Pahlavi, se geboorte in Teheran.

12 Des 1925 Reza Khan word as die Sjahinsjah van Iran deur die Majlis (parlement) benoem.

25 Apr 1926 Kroningsplegtigheid van Reza Khan; Mohammed Reza word kroonprins.

25 Aug 1941 Britse en Russiese troepe val Iran binne.

26 Aug 1941 Iran gee oor.

16 Sep 1941 Reza Khan abdikeer.

17 Sep 1941 Verdeling van Iran deur die Britte en Russe is afgehandel. Kroonprins Mohammed Reza word beëdig as Sjahinsjah van Iran.

1 Des 1943 Konferensie van Geallieerdes. Hul beloof om Iran te verlaat sodra die oorlog verby is.

1946 Britse troepe verlaat Iran.

Mrt 1946 VSA berig dat die USSR besig is om sy troepe in Iran te versterk. Die USSR het die volgende eise gestel:

(1) uitgebreide tydperke van verblyf van Russiese troepe,

(2) Iranese erkenning van die Russies geïnisieerde Volksrepubliek van Azerbaijan;

(3) stigting van 'n gesamentlike Russies-Iranese petro- leum eksploitasiemaatskappy met ' $n$ Russiese meerderheidsbeheer.

9 Mei 1946 Russiese troepe word onttrek uit Iran as gevolg van toenemende internasionale druk en die oliekonsessies.

15 Des 1946 Sjah begelei sy troepe na Azarbaijan en herstel die Iranese soewereiniteit daar.

4 Feb 1949 Sluipmoordpoging op die Sjah by die Universiteit van Teheran.

$28 \mathrm{Mrt}$ Dr Mohammed Mossadegh word Eerste Minister.

13-22 Jul 1952 Dr Mossadegh bedank. word egter na onluste weer aangestel.

16 Aug 1953 Regering kondig aan dat gepoogde staatsgreep deur die Keiserlike Eenheid afgeweer is. Sjah vlug na Baghdad en toe na Rome. Dr Mossadegh ontbind die parlement. Genl Fazulla Zahedi kondig aan dat die Sjah hom aangestel het as Eerste Minister.

19 Aug 1953 Omverwerping van dr Mossadegh se regering deur genl Zahedi en die Koninklike Magte.

21 Aug 1953 Sjah keer terug na Iran.

11 Okt 1955 Iran word lid van die Baghdad-verdrag, lateraan bekend as Cento.

11 Nov 1961 Sjah kondig sy ses-puntplan vir sosio-ekonomiese hervormings aan.

Jan 1963 Landswye steun vir hervorming verkry dmv referendum.

1964 Ayatollah el Sayyed Royhallah el Khomeini, geestelike leier van die Shii- 
gemeenskap, word verban.

1972-3 Reeks massaverhore en vervolgings. Die belangrikste geheime opposisiepartye was: Tudeh, Bond van Iranese Sosialiste en die Islamitiese Volkeparty.

Nov/Des 1973 Op versoek van Sultan Qaboos stuur die Sjah van sy troepe na Oman om te help veg teen die Marxistiese ondersteunde Suid-Yemen guerillas.

2 Mrt 1975 Sjah kondig eenparty-staat aan. Enigste erkende party is die Rastakhiz Party.

2 Jun 1975 Algemene verkiesing.

26 Jan 1977 Terugtrekking van Iranese troepe uit Oman.

Apr 1977 Arrestasie van Ali-Naghi Rabbani, penetrasie van KGB-lede in die hoë sosiale kringe van Iran word bekend.

7-9 Jan 1978 Betogings in Qom tgv Khomeini verander in gewelddadige onluste, baie sterf.

18 Feb 1978 Onluste in Tabriz.

17 Mrt 1978 Onluste versprei, ook in Teheran, Qazriu en Yazd.

27 Apr 1978 Sowjet ondersteunde staatsgreep in Afganistan.

7 Jun 1978 Genl Moghadam vervang genl Nassiri as hoof van die SAVAK.

12 Aug 1978 Krygswet word afgekondig.

19 Aug 1978 Aanval op Rex Teater in Abadan.

27 Aug 1978 Jaafar Sharif-Emami word aangestel as Eerste $\mathrm{Mi}$ nister.
29 Aug 1978 Hua Kuo-Feng van China arriveer in Iran vir samesprekings met die Sjah.

8 Sep 1978 Krygswet afgekondig in Teheran, Tabriz, Qazriu, Karaj, Mashhad, Qom, Alwaz, Kazeruu, Shiraz, Jahrom en Abadan.

1 Okt 1978 Oproep tot landswye staking deur die leiers van die Nasionale Front en die Sjiiete agv botsings tussen Irakse en Iranese bevolking. Amnestie word aan Khomeini verleen.

10 Okt 1978 Khomeini arriveer in Parys.

31 Okt 1978 Petroleum-werkers staak vra vir beëindiging van Krygswet en vrylating van politieke gevangenes.

3 Nov 1978 Khomeini sê in 'n Radiouitsending 'Shah and his dynasty must go. Up to now I have not given my agreement for starting a civil war, but that could change.'

5 Nov 1978 Onluste in Teheran. Die Eerste Minister, SharifEmami, bedank.

6 Nov 1978 Militêre regering onder genl Azhari word ingestel.

8 Nov 1978 Arrestasie van Amir Abba Hoveida, voormalige Eerste Minister, en genl Nematollah Nassiri, voormalige hoof van SAVAK.

11 Nov 1978 Dr Karim Sanjabi, leier van die Nasionale Front, word gearresteer.

28 Des 1978 Olieproduksie kom tot stilstand in Iran.

30 Des 1978 Dr Shapur Baktiar deur Sjah aangestel as Eerste Minister. 
7 Jan 1979 Oproep om algehele staking aan arbeiders deur opposisie in Iran.

9 Jan 1979 Bedanking van geni Jam as Minister van Verdediging. Genl Abdolali Badrei volg hom op.

10 Jan 1979 VSA-vloot en lugmageenhede beweeg nader aan die Persiese Golf.

11 Jan 1979 Besluit om olieverkope aan Suid-Afrika en Israel te staak.

16 Jan 1979 Sjah verlaat Iran. Vertrek na Egipte.

17 Jan 1979 Minister van Justisie, mnr Sadig-Vaziri, bedank uit Baktiar-kabinet.

21 Jan 1979 Iranese Lugmagpersoneel eis dat die Amerikaanse raadgewers moet padgee. Terugroeping van Iran se ambassadeurs in USSR en Saoedi-Arabië.

22 Jan 1979 Sjah kom aan in Marokko.

30 Jan 1979 Amerikaanse Ambassadepersoneel kry opdrag om na die VSA terug te keer.

31 Jan 1979 Magsvertoon van Leër in Teheran-strate.

8 Feb 1979 Khomeini kom in Iran aan en neem beheer oor. Hy stel dr Mehdi Bazargan aan as hoof van die voorlopige regering.

11 Feb 1979 Die regering van Shapur Baktiar, wat die skyn van bewind probeer behou het, word tot ' $n$ val gebring en hy vlug na Marokko.

12 Feb 1979 Pakistan erken die nuwe regering. Die USSR en die VSA begin met diplomatieke onderhandelinge.
13 Feb 1979 Iran verbreek bande met Israel.

14 Feb 1979 Die Amerikaanse ambassade in Teheran word deur ' $n$ radikale faksie van die Islamitiese Revolusionêre Raad beset.

18 Feb 1979 VSA stuur protesnota aan die USSR waarin beswaar aangeteken word oor Russiese inmenging in Iran. Dr Bazargan bevestig dat olie nie aan Israel en Suid-Afrika verskaf sal word nie. Die PLO verstewig hul posisie in Iran.

19 Feb 1979 Suid-Afrika onttrek sy diplomatieke personeel uit Iran. Israeli's word uit Iran verdryf.

22 Feb 1979 Onluste onder Kurdi-stam. Kurdi-stam wil as 'n onafhanklike entiteit in Iran bestaan.

23 Feb 1979 'n Woordvoerder van die Iranse ambassade in Washington maak bekend dat Iran sy ekonomiese bande met die RSA gaan verbreek. In die Kurdiese dorp Mahabad ontruim Iranese troepe hul kwartiere om botsings met Kurdiese nasionaliste te vermy.

25 Feb 1979 Ajatolla Khomeini veroordeel VSA, USSR, China en Brittanje oor hul ondersteuning van die Sjah en verklaar terselfdertyd dat Iran met ander lande goeie betrekkinge op 'n grondslag van wedersydse agting wil hê

26 Feb 1979 Uit Teheran word berig dat die revolusionêre leiers in Iran spesiale kommandoeenhede op die been gebring het om misdadigers wat uit die land gevlug het, op te spoor en uit te wis. 
27 Feb 1979 Die hoof van Iran se oliebedryf, Hassan Nazih, kondig aan dat dié land sy olieuitvoere gaan hervat op die grondslag van regstreekse afset aan die hoogste bieder. Dié besluit maak 'n einde aan die monopolie van die Westerse konsortium onder aanvoering van British Petroleum wat Iran se uitvoere in die verlede beheer het.

1 Mrt 1979 Ajatolla Khomeini verlaat Teheran om hom te vestig in Qom waar hy 15 jaar vantevore in hegtenis geneem is. Die premier, dr Mehdi Bazargan, dreig om te bedank as die onrus in die land voortduur. Sy kritiek is veral gerig op die bedrywighede van radikale groepe wat die gereg in eie hande neem.

16 Mrt 1979 Ajatolla Khomeini beveel dat alle politieke verhore na aanleiding van kritiek deur die Premier Bazargan oor 'n vlaag van teregstellings gestaak word. Hierdie reëling was egter van korte duur, kort na hierdie aankondiging is daar tog nog voortgegaan met die teregstellings. Daar word aangekondig dat die revolusionêre howe onder regeringsbeheer gebring gaan word.
19 Mrt 1979 Hewige skermutselinge tussen Kurdieserebelle en regeringsmagte woed in Sanadaj nadat die rebelle die plaaslike radiostasie beset en die leërbarakke aangeval het. Elders in die land hou militêre eenhede parades om hul solidariteit met die Islamitiese revolusie te betuig.

21 Mrt 1979 Skermutselinge tussen Kurdiese rebelle en regeringsmagte kom tot ' $n$ einde. Sowat 200 mense is in die gevegte dood.

27 Mrt 1979 Gevegte woed in die dorp Gonbad Kavus tussen Turkomaanse stamlede en regeringsoldate. Die stafhoof van die weermag, genl-maj Mohammed Gahrani word afgedank.

20 Apr 1979 Die staatsradio in Iran maak bekend dat nog vyf lede van die gewese regering van die Sjah tereggestel is. Dit bring die aantal teregstellings sedert die Sjah Iran verlaat het op 147 te staan. Onder die tereggesteldes was genl lazollah Gafari, 'n voormalige polisiehoof, en Mohammed Taghi Javan, gewese hoof van die Geheime Polisie. 


\section{VOETNOTE}

(a) Bhutto, Z.A., The Myth of Independence, London, 1969, p 28.

(b) Váli, I.A., Politics of the Indian Ocean Region: The Balances of Power, London 1976, p 36

(c) Palmieri, A.L., La Politica asiatica dei Bolscevichi, Bologna 1924, p 173

\section{BIBLIOGRAFIE}

1. Darbey. P.: British Defence Policy East of Suez 1947-1968, 1ste uitgawe. Oxford University Press, London, 1973.

2. Black, C.E., Thornton, T.P. (ed): Communism and Revolution: The Strategic Uses of Political Violence, 1ste uitgawe. Princeton University Press, Princeton, 1964.

3. Burrell, R.M., Cottrell, A.J.: Iran, The Arabian Peninsula and the Indian Ocean, 1ste uitgawe. Strategy Papers no 14, National Strategy Information Center Inc., New York, 1972.

4. Ellwell-Sutton, L.P.: Modern Iran, 1ste uitgawe. London, 1941.

5. Seton-Watson, H.: Nationalism and Communism - Essays 1946-1963, 1ste uitgawe. Methuen \& Co Ltd., London, 1964.

6. Turner, C.: Oil companies in the International System, 1ste uitgawe. George Allan \& Unwin (Publishers) Ltd., London, 1978.

7. Abir, M.: Oil, Power and Politics: Conflict in Arabia, The Red Sea and the Gulf, 1ste uitgawe. Frank Cass \& Co Ltd., London, 1964.

8. Adie, W.A.C.: Oil Politics and Sea Power, 1ste uitgawe. New York, 1975

9. Lenczowski, G.: Oil and State in the Middle East, 1ste uitgawe. Cornell University Press, New York, 1960.

10. Langrigg, S.H.: Oil in the Middle East, 1ste uitgawe. Oxford University Press, Oxford, 1954

11. Odell, P.R.: Oil and World Power: Background to the Oil Crisis, 3de uitgawe. Penguin Books Ltd., Middlesex, 1974.

12. Váli, I.A.: Politics of the Indian Ocean Region: The Balances of Power, 1ste uitgawe. Collier MacMillan Publishers, London, 1976.

13. Fairhall, D.: Russia Looks to the Sea: A study of the Expansion of Soviet Maritime Power, 1ste uitgawe. André Deutsch Ltd., London, 1971.

14. Fisher, S.N.: Social Forces in the Middle East, 1ste uitgawe. Cornell University Press, New York, 1955.

15. Chubin, S., Zabin, S.: The Foreign Relations of Iran: A Developing State in a Zone of Great Power Conflict, 1ste uitgawe. University of California Press, London, 1974.

16. The Gulf: Implications of British Withdrawal, 1ste uitgawe. Georgetown University, Washington, 1969.

17. Upton, J.M.: The History of Modern Iran: An Interpretation, 1ste uitgawe. Harvard University Press. 1960.

18. The Middle East and North Africa 1976-77, 23ste uitgawe. Europa Publications Ltd., London, 1978.

19. The Military Balance 1978-79.

20. Burrell, R.M.: The Persian Gulf, 1ste uitgawe. Sage Publications, London, 1972.

21. Lacqueur, W.: The Struggle for the Middle East: The Soviet Union and the Middle East 1958-68, 1ste uitgawe. Routledge and Kegan Paul, London, 1969.

22. 'Iran: Weapons and Oil', Aviation and Marine, 1976-

23. 'Senate Unit Questions Iran Arms Buys', Aviation Week and Space Technology, 9 August 1976.

24. Kedouri, E.: 'Islamic Marxists - Contradiction in Terms?'. Conflict Studies, No 100: Oktober 1978.
25. Bailly, Sir L.L., (vice-adm), 'Some Thoughts on Technology and Conflict'. Conflict Studies, No 100: Oktober 1978.

26. 'The Campaign to Destabilise Iran', Conflict Studies, No 101 1978.

27. 'Iran - 'n Grootmoondheid in Wording Deel 1 - III', Die Wêreld in Oënskou, 1975.

28. 'Quiet, but the trade is there', Financial Mail, Vol 69 No 2: 14 Julie 1978.

29. 'Practorian Solution in Iran', Foreign Report, 8 November 1978

30. 'Iran: an analysis', Intelligence Digest, 10 Januarie 1979.

31. Burrell, R.M.: 'Iranian Foreign Policy. Strategic Location, Economic Ambition, and Dynastic Determination', Journal of International Affairs, Vol 29 № 2: 1978.

32. Golden, J.: 'Iran - Strategic Keystone', National Defense, November/Desember 1978

33. "Iran: at the Brink?", Newsweek, Vol 2 No 20: November 13, 1978

34. Butler, D., "Iran at the Brink", Newsweek, Vol 92 No 25: 18 Desember 1978

35. Butler, D., 'Iran's Eleventh Hour', Newsweek, 22 Januarie 1979

36. Butler, D., 'Iran after the Shah', Newsweek, 29 Januarie 1979

37. 'Iran: Carrot and Stick', Newsweek, Vol 92 No 13: 25 September 1978.

38. 'Russia's Blue-Water Bid', Newsweek, 21 Februarie 1977.

39. 'Iranian Defence - Budget and Potentials', Political Survey, No $122: 1977$

40. Hughes, E.: "Soviet Strategy in the Indian Ocean, Reader's Digest, Vol 100 : Mei 1972.

41. Friggens, P., "Iran : Keystone of the Middle East", Reader's Digest, Oktober 1973.

42. Sheehan, E.: 'Mastermind of Arab Oil', Reader's Digest, November 1974

43. Rowan, C., 'Superman of the New Iran', Reader's Digest, Apri 1976.

44. 'Now it is up to the Shah', Time, 22 Januarie 1979.

45. 'Another Crisis for the Shah', Time, Vol 112 No 20: 13 November 1978.

46. 'Relative Calm, Time, 4 Desember 1978

47. 'Opec: No Boost till June - If Then', Time, 2 Januarie 1978.

48. 'What Price OPEC Unity?', Time, 26 Desember 1977.

49. 'The Shah's Divided Land', Time, 18 September 1978

50. 'The Military is in Charge', Time, Vol 112 No 22, 27 November 1978

51. 'The Shah's Fight for Survival', Time, Vol 112 No 21: 20 November 1978 .

52. 'The Weekend of Crisis', Time, Vol 112 No 25, 18 Desember 1978.

53. 'Hard Choices in Teheran', Time, 25 Desember 1978

54. 'The Army or the Void', The Economist, Vol 269 No 7054, 11 November 1978 'When the Policeman's Gone', The Economist, 27 Januarie 1979. Jansen, G.: 'Militant Islam', The Economist, 27 Januarie 1979. 
57. Weinbaum, M.G., 'Agricultural Policy and Development Politics in Iran', The Middle East Journal, Vol 3 No 4: 1977.

58. Duyzings, M.W., 'A Mission on behalf of the Shah', To the Point. 1 Desember 1978

59. 'Russian moves for Red Sea Control', To the Point, 28 Julie 1978.

60 'The Shah wants to build a regional super-power', To The Point, 17 Februarie 1978.

61. 'Shah's visit full of Paradoxes', To The Point, 25 November 1977.

62. 'Shah on a tightrope', To The Point, 22 September 1978.

63. 'More nails in the Iranian Coffin', To The Point, 10 November 1978.

64. 'Iran's Painful Entry into the Modern World', U.S. News and World Report, 7 Augustus 1978 .

65. Argus, $17.1 .79 ; 19.1 .79 ; 24.1 .79 ; 25.1 .79 ; 9.2 .79 ; 15.2 .79$

66. Beeld, $30.12 .78 ; 17.1 .79 ; 25.1 .79 ; 26.1 .79 ; 29.1 .79 ; 30.1 .79$ $31.1 .79 ; 17.2 .79 ; 19.2 .79 ; 20.2 .79 ; 22.2 .79$.

67. Burger, 12.1.79; 13.1.79; 22.1.79; 23.1.79; 27.1.79; 29.1.79; $13.2 .79 ; 14.2 .79 ; 17.2 .79 ; 20.2 .79$.

68. Cape Times, $16.1 .79 ; 22.1 .79 ; 24.1 .79 ; 27.1 .79 ; 13.2 .79 ; 14.2 .79$

69. Citizen, $8.1 .79 ; 17.1 .79 ; 20.1 .79 ; 24.1 .79 ; 25.1 .79 ; 26.1 .79$; $31.1 .79 ; 1.2 .79 ; 5.2 .79 ; 19.2 .79 ; 20.2 .79 ; 21.2 .79$.

70. Daily Dispatch, $14.12 .78 ; 29.12 .78 ; 16.1 .79 ; 18.1 .79 ; 19.1 .79$; 22.1.79; $24.1 .79 ; 25.1 .79 ; 29.1 .79 ; 17.2 .79$.

71. Daily News, 29.12.78; 11.1.79; 13.1.79; 16.1.79; 22.1.79; 20.2.79.

72. Diamond Fields Advertiser, $16.1 .79 ; 23.1 .79 ; 24.1 .79 ; 29.1 .79$.

73. Eastern Province Herald, 15.12.78; 10.1.79; 15.1.79; 22.1.79; $26.1 .79 ; 27.1 .79 ; 29.1 .79 ; 15.2 .79 ; 19.2 .79$
74. Evening Post, 29.12.78; 8.1.79; 16.1.79; 22.1.79; 23.1.79; $24.1 .79 ; 26.1 .79 ; 12.2 .79 ; 15.2 .79 ; 16.2 .79$.

75. Friend, $12.1 .79 ; 25.1 .79$.

76. Hoofstad, 20.1.79; 23.1.79; 30.1.79; 5.2.79; 16.2.79; 17.2.79.

77. Natal Mercury, 12.1.79; 13.1.79; $16.1 .79 ; 23.1 .79 ; 24.1 .79$; $25.1 .79 ; 27.1 .79 ; 17.2 .79$.

78 Natal Witness, $29.12 .78 ; 30.12 .78 ; 15.1 .79 ; 16.1 .79 ; 29.1 .79$ $30.1 .79 ; 17.2 .79 ; 19.2 .79 ; 21.2 .79$.

79. Oggenblad, $29.12 .78 ; 20.1 .79 ; 24.1 .79 ; 5.2 .79 ; 17.2 .79 ; 19.2 .79$.

80. Oosterlig, 8.1.79; 9.1.79; 10.1.79; 11.1.79; 16.2.79.

81. Post, 8.1.79.

82. Pretoria News, $30.12 .78 ; 13.1 .79 ; 18.1 .79 ; 19.1 .79 ; 20.1 .79$; $24.1 .79 ; 30.1 .79 ; 13.2 .79$.

83. Rand Daily Mail, 8.1.79; 19.1.79; $25.1 .79 ; 31.1 .79 ; 1.2 .79$; 20.2.79.

84. Star, $15.1 .79 ; 16.1 .79 ; 18.1 .79 ; 23.1 .79 ; 27.1 .79 ; 30.1 .79 ; 5.2 .79$; $19.2 .79 ; 21.2 .79$

85. Sunday Post, 21.1.79.

86. Times of Swaziland, 13.2.79.

87. Die Transvaler, 15.1.79; 16.1.79; 17.1.79; 19.1.79; 22.1.79; $25.1 .79 ; 27.1 .79 ; 31.1 .79 ; 5.2 .79 ; 19.2 .79$.

88. Die Vaderland, $30.12 .78 ; 30.1 .79$

89. Volksblad, $30.12 .78 ; 8.1 .79 ; 17.1 .79 ; 29.1 .79 ; 13.2 .79 ; 14.2 .79$; $15.2 .79 ; 16.2 .79$. 